Special Issue: Agricultural Productivity and Sustainability Improvement in Tropical Region

\title{
Blood Profile of Soybean Meal Substitution with Black Soldier Fly Larvae in New Zealand White Rabbit
}

\author{
Ardi Prasetio ${ }^{1 *}$, Christina Maria Sri Lestari ${ }^{2}$, Sutaryo Sutaryo², Manar Fayiz Mousa Atoum ${ }^{3,4}$, \\ Muhammad Zahoor ${ }^{5}$, Asma Nisar ${ }^{6}$ and Muhannad Illayan Massadeh ${ }^{7}$
}

${ }^{1}$ Magister Student of Animal Science, Faculty Animal and Agriculture Science, Diponegoro University, Jl. Prof. Sudarto No.13, Tembalang, Semarang 50275, Central Java, Indonesia; ${ }^{2}$ Department Animal Science, Faculty Animal and Agriculture Science, Diponegoro University, Semarang, Central Java, Indonesia; ${ }^{3}$ Molecular Biology and Genetics, The Hashemite University, PO Box 330127, 13133 Zarqa, Jordan; ${ }^{4}$ Department of Medical Laboratory Sciences, The Hashemite University, Zarqa, Jordan; ${ }^{5}$ Department of Biochemistry, University of Malakand, Lower Dir 18800, Malakand, Pakistan; ${ }^{6}$ Nazar College of Pharmacy, DAKSON Institue of Health Sciences, Main Murree Road, Barakahu, 45400 Islamabad, Pakistan; ${ }^{7}$ Department of Biological Sciences and Biotechnology, Faculty of Science, The Hashemite University, PO Box 330127, 13133 Zarqa, Jordan.

Abstract | Meat consumption in Indonesia is dominated by high-cholesterol meat that can lead to several cardiovascular diseases. Rabbits (Oryctolagus cuniculus Linnaeus, 1758), known as low cholesterol meat, can be alternatively chosen for daily consumption. Soybean meal (SBM), as the primary protein source in rabbit ration, has some disadvantages. Protein value in Black Soldier Fly Larvae -BSFL (Hermetia illucens Linnaeus, 1758 ) is equal to SBM and better in the amino acid profile. However, the chitin contained in BSLF may cause subclinical inflammation by blood parameter detection. Thus, this study investigated the BSLF substitution effect on rabbit blood traits. This study was performed using 28 wk old weaned male New Zealand White rabbits (1300 g $\pm 130 \mathrm{~g}$ ) that were randomly divided into control group (T0) and treatment group (T1, T2, T3), which respectively substituted 0\%, $10 \%, 20 \%$, and $30 \%$ SBM with BSFL. Blood samples were collected from the right ear marginal vein. The result showed an increasing trend of leukocytes and neutrophils in the treatment group $(P>0.05)$ that implicated the inflammation occurrence. The body responded to chitin as Pathogen Associated Molecular Pattern (PAMP) to trigger the inflammation. BSLF can substitute SBM. However, it needs further study to eliminate the inflammation response caused by chitin in BSLF.

Received | October 13, 2021; Accepted | December 13, 2021; Published | December 28, 2021

*Correspondence | Ardi Prasetio, Magister Student of Animal Science, Faculty Animal and Agriculture Science, Diponegoro University, Semarang, Central Java, Indonesia; Email: prasetio.ardiben@gmail.com

Citation | Prasetio, A., C.M.S. Lestari, S. Sutaryo, M.F.M. Atoum, M. Zahoor, A. Nisar and M.I. Massadeh. 2021. Blood profile of soybean meal substitution with black Soldier Fly Larvae in New Zealand white rabbit. Sarhad Journal of Agriculture, 37(Special issue 1): 110-114.

DOI | https://dx.doi.org/10.17582/journal.sja/2021/37.s1.110.114

Keywords | Alternative protein substitute, Feed replacement, Hematology, Hermetia illucens Linnaeus, 1758, Oryctolagus cuniculus Linnaeus, 1758

\section{Introduction}

$\mathrm{B}$ eef and chicken, which have high-level cholesterol, are mainly consumed in Indonesia and can lead to several kinds of cardiovascular disease, including stroke and heart failure (D.J.P.K.H., 2017; LloydJones, 2010; Zotte and Szendrö, 2011). In Indonesia, beef and chicken consumption was about $0.538 \mathrm{~kg}$ capita $^{-1} \mathrm{mo}^{-1}$ while cardiovascular-related disease increased from $25.8 \%$ in 2013 to $34.1 \%$ in 2018 . This increase might be related to the consumption of highlevel cholesterol meat, including beef and chicken that contain (60 to 114) mg $100 \mathrm{~g}^{-1}$ cholesterol. On the other hand, rabbits (Oryctolagus cuniculus Linnaeus, 1758) include $56.4 \mathrm{mg} 100 \mathrm{~g}^{-1}$ cholesterol, an alternative daily meat consumption since they have 
lower cholesterol meat. In addition, rabbits have a high reproductive rate and can be massively produced in a short period (Khan et al., 2016). The gestation time takes about $30 \mathrm{~d}$ to $31 \mathrm{~d}$ and can reach up to 12 litter sizes at birth (Megan et al., 2015).

Increasing the rabbit productivity needs intensified treatment, including giving high nutritious feed containing several ingredients that meet the daily rabbit nutrition requirement, such as pelleted ration (Rahman et al., 2015). The intensified rabbit farms utilize soybean meal (SBM) as the main protein source in ration due to high protein value and its low price (Mauer et al., 2016). However, in Indonesia, SBM is fully imported mainly from America and causes fluctuating prices of SBM due to the Rupiah (IDR) to Dollars (USD) exchange rate. These facts lead to the unstable rabbit meat price that finally may disrupt national food security (Bantacut, 2017). Thus it is necessary to find an alternative protein source to substitute SBMs.

The protein value in Black Soldier Fly Larvae-BSFL (Hermetia illucens Linnaeus, 1758) is equal to SBM and even better in the amino acid profile (Makkar et al., 2014). Previous research has reported the increased productivity in layer hen and broiler (Gallus gallus Linnaeus, 1758), while another research found the decreased productivity and digestibility after being fed by BSFL (Cutrignelli et al., 2017; Mauer et al., 2016; Mwaniki et al., 2018). Chitin was assumed to be the factor that caused this result due to chitin inhibiting protein absorption. Furthermore, it was also reported that chitin which formed the exoskeleton of BSLF, caused subclinical inflammation. However, the symptoms could only be observed using hematology parameters, including the white blood cells (WBC) profile (Burton and Zaccone, 2007).

As one of the blood profile parameters, WBCs have an important role in protecting the body from foreign pathogenic and harmful agents through the inflammation process (Moore et al., 2015), thus determining the WBCs population would show the body condition regarding inflammation after consuming alternative ration. Furthermore, red blood cells (RBCs) and hemoglobin might also show physiological change after consuming alternative persentages regarding the capacity to transport the digested nutrients. Therefore, determining the blood profile such as RBCs, hemoglobin (Hb), and WBCs would reveal the effect of SBMs substitutions with BSLF meal (SBMs-BSLFM).

\section{Materials and Methods}

\section{Experimental design and diet preparation}

This study was performed on a local rabbit farm in Meteseh, Tembalang District, Semarang, Indonesia, under ethical clearance approval from Sultan Agung Islamic University with approval number 629/X/2019. The SBM and SBLF were purchased from the Animal Science Laboratory of Diponegoro University, Semarang, Indonesia. A total of 20 weaned male New Zealand White rabbits, 8 wk old, weighing $1300 \mathrm{~g} \pm 130 \mathrm{~g}(\mathrm{cv}=10 \%)$, purchased from a local farmer, were randomly divided into one control group (T0) and three treatment groups (T1, T2, T3), which respectively substituted $0 \%, 10 \%, 20 \%$, and $30 \%$ SBMs with BSFL M. Rabbits were reared for $10 \mathrm{wk}$ and fed ad libitum in battery cages under $26{ }^{\circ} \mathrm{C}$ to $31{ }^{\circ} \mathrm{C}$ temperature, $70 \%$ humidity.

\section{Blood sample collection}

The whole blood samples were collected at the end of rearing time using a $3 \mathrm{cc}$ syringe from the marginal vein of the right ear. The blood samples were put into an EDTA-contained blood tube to prevent clotting and transferred in a cool box to the laboratory for analysis. Red Blood Cells (RBCs), White Blood Cells (WBCs), Haemoglobin ( $\mathrm{Hb})$, and differentiated WBCs were analyzed using BC-3600 Mindray automated cell counter (Shenzhen Mindray BioMedical Electronics $\left.{ }^{\circledR}\right)$.

\section{Statistical analysis}

One way Analysis of Variance (ANOVA) was performed by IBM SPSS (V. 24.0) to determine the difference between treatments (Adinurani, 2016).

\section{Results and Discussion}

This study showed no significant result in every blood profile parameter $(P>0.05)$ as shown in Table 1. However, a slight increase trend of WBCs was shown in BSLFM substitution.

Black soldier fly larvae are one of the potential protein sources to substitute SBM in rabbit ration due to their high protein and amino acid profile value. Chitin mainly forms the exoskeleton of insects, inhibits protein absorption, and causes subclinical 
Table 1: Blood profile of rabbit in BSLF substitution.

$\begin{array}{llllll} & \text { T0 } & \text { T1 } & \text { T2 } & \text { T3 } & \text { Sig } \\ \text { RBCs }\left(x 10^{3}\right) & 4.83 \pm 1.51 & 5.64 \pm 0.18 & 6.10 \pm 0.47 & 5.93 \pm 0.36 & 0.30 \\ \text { Hb }\left(\mathrm{g} \mathrm{dl}^{-1}\right) & 10.70 \pm 3.38 & 12.63 \pm 0.77 & 13.23 \pm 0.56 & 13.20 \pm 0.69 & 0.33 \\ \text { WBCs }\left(\mathrm{x} 10^{3}\right) & 7.16 \pm 4.65 & 7.36 \pm 3.93 & 10.63 \pm 5.15 & 12.56 \pm 5.00 & 0.46 \\ \text { Neutrophils }(\%) & 63.66 \pm 5.85 & 69.00 \pm 6.08 & 59.67 \pm 11.71 & 67.67 \pm 2.51 & 0.44 \\ \text { Lympocytes }(\%) & 29.67 \pm 4.72 & 25.00 \pm 5.19 & 34.67 \pm 10.11 & 26.67 \pm 2.08 & 0.31 \\ \text { Mononocytes }(\%) & 6.67 \pm 1.15 & 6.00 \pm 1.00 & 5.67 \pm 2.88 & 5.67 \pm 0.57 & 0.86\end{array}$

RBCs: Red blood cells; Hb: Hemoglobin; WBCs: White blood cells.

inflammation and some health disorders, including asthma and allergy, that cannot be seen visually in the animal (Burton and Zaccone, 2007).

This study revealed that the RBCs and Haemoglobin were in the normal physiological range. On the other side, the treatment groups showed the overpopulation of leukocytes (Moore et al., 2015). The elevated WBCs number indicated inflammation in response to the feed ingredients contained in the ration (Ahluwalia et al., 2013). White blood cells generally play an essential role in removing harmful foreign substances that might be included in feed ingredients, and their number would increase along with the existence of these substances (Chmielewski and Strzelec, 2018; Moore et al., 2015). The inflammation process can be triggered by several factors, including pathogen or damage molecule pattern exposure.

Chitin which is the peritrophic matrix of insects, was reported to be one of the pathogen-associated molecular patterns (PAMP) that would trigger the initial inflammatory response in animals once they were exposed to the body (Da Silva et al.,2009; Klauser et al., 2013; Mogensen, 2009). This complex process would induce some pro-inflammatory cytokines production, such as Interleukin-6 (IL-6), Tumor necrotic factor $\alpha(\mathrm{TNF}-\alpha)$ that will recruit more leukocytes to remove the PAMP-related chitin from the body (Da Silva et al., 2009; Koller et al., 2011). At the same time, IL- 6 and TNF- $\alpha$ production caused by inflammation can reduce rabbit appetite leading to lower productivity (Broom and Kogut, 2017; Sieske et al., 2019). However, symptoms of inflammation were not observed visually during the rearing period.

The limitation of this research was not investigating the pro-inflammatory cytokine, including IL-6 and TNF $\alpha$ level, that would confirm the inflammation occurs in rabbits fed BSLF substitution.

\section{Conclusions and Recommendations}

Substitution of soybean meals with black soldier fly larvae meals showed the normal condition of blood profile parameters. However, the increasing trend of leucocytes can indicate that inflammation occurs in the rabbit body, leading to reduced productivity. The chitin contained in BSLF needs further consideration due to triggering the inflammation process.

\section{Novelty Statement}

BSLF as an alternative protein source became a significant concern due to its high protein profile and sustainability. However, the study regarding BSLF as a protein source in the ration is limited to poultry and fishery. In addition, there is less study to analyze the effect of BSLF in rabbits; thus, this study investigated the impact of SBMs substitutions with BSLF (SBMsBSLF) on the rabbit blood profile.

\section{Author's Contribution}

AP: Conceptualized and designed research, elaborated intellectual content, carried out experimental studies, data acquisition, data analysis, statistical analysis and revised manuscript.

CMSL: Performed literature search and reviewed manuscript.

SS: Analyzed data and reviewed manuscript.

MFMA, MZ and MIM: Elaborated intellectual content, performed literature search, reviewed manuscript and guarantor.

AN: Elaborated academic content, completed literature search, reviewed manuscript.

All authors read and approved the final manuscript

\section{Conflict of interest}

The authors declare that there is no conflict of interest 
regarding the publication of this article

\section{References}

Adinurani, P.G. 2016. Design and analysis of agro trial data: Manual and SPSS. Plantaxia, Yogyakarta, Indonesia

Ahluwalia, N., V.A. Andreeva, E.K. Guyot and S. Hercberg. 2013. Dietary patterns, inflammation, and the metabolic syndrome Diabetes $\mathrm{Me}-$ tab J., 39(2): 99-110. https://doi.org/10.1016/j. diabet.2012.08.007

Bantacut, T. 2017. Soybeans development for food sovereignty, industrial, and economy. J. Pangan, 26(1): 81-96.

Broom, L.J. and M.H. Kogut. 2017. Inflammation: friend or foe for animal production?. Poult. Sci., 97(2): 510-514.

Burton, O.T. and P. Zaccone. 2007. The potential role of chitin in allergic reactions. Trends Immunol., 28(10): 419-422. https://doi. org/10.1016/j.it.2007.08.005

Chmielewski P.P. and B. Strzelec, B. 2018. Elevated leukocyte count as a harbinger of systemic inflammation, disease progression, and poor prognosis: a review. Folia Morphol., 77(2):171178. https://doi.org/10.5603/FM.a2017.0101

Cutrignelli, M.I., M. Messina, F. Tulli, B. Randazzo, I. Olivotto, L. Gasco, R. Loponte, R., and F. Bovera. 2017. Evaluation of an insect meal of the Black Soldier Fly (Hermetia illucens) as soybean substitute: Intestinal morphometry, enzymatic and microbial activity in laying hens. Vet. Sci. Res. J., 117: 209-215. https://doi. org/10.1016/j.rvsc.2017.12.020

Da Silva, C.A., C. Chalouni, A.Williams, D. Hartl, C.G. Lee and J.A Elias. 2009. Chitin is a sizedependent regulator of macrophage $\mathrm{TNF}$ and IL-10 production. J. Immunol. Res., 182(6): 3573-3582. https://doi.org/10.4049/jimmunol.0802113

D.J.P.K.H. 2017. Livestock and animal health statistic. Direktorat Jenderal Peternakan dan Kesehatan Hewan, Kementerian Pertanian RI. Jakarta.

Janssen, N.B, T.H. Westhoff, R. Wirth and M. Pourhassan. 2019. Inflammation, appetite and food intake in older hospitalized patients. Nutrients, 11: 1-10. https://doi.org/10.3390/ nu11091986

Khan, K., S. Khan, R. Khan, A. Sultan, N.A. Khan and N.Ahmad. 2016. Growth performance and meat quality of rabbits under different feeding regimes. Trop. Anim. Health Prod., 48(6): 1661-1666. https://doi.org/10.1007/s11250016-1140-4

Klauser, D., P. Flury, T. Boller and S. Bartels. 2013. Several MAMPs, including chitin fragments, enhance AtPep-triggered oxidative burst independently of wounding. Plant Signal. Behav., 8(9): e253461-e253463. https://doi. org/10.4161/psb.25346

Koller, B., A.S. Muller-Wiefel, R. Rupec, H.C. Korting and T. Ruzicka. 2011. Chitin modulates innate immune responses of keratinocytes. PLoS One, 6(2): 1-7. https://doi.org/10.1371/ journal.pone.0016594

Lloyd-Jones, D.M. 2010. Cardiovascular risk prediction: basic concepts, current status, and future directions. Circulation, 121(15): 1768 -1777. https://doi.org/10.1161/CIRCULATIONAHA.109.849166

Makkar, H.P.S., G. Tran, V. Heuzé and P. Anker. 2014. State of the art on use of insects as animal feed. Anim. Feed Sci. Technol., 197: 1-33. https://doi.org/10.1016/j.anifeedsci.2014.07.008

Mauer, V., M. Holinger, Z. Amsler, B. Fruh, J. Wohlfahrt, A. Stamer and F. Leiber. 2016. Replacement of soybean cake by Hermetia illucens meal in diets for layers. J. Insect. Food Feed, 2(2): 83-90. https://doi.org/10.3920/ JIFF2015.0071

Megan, N.H., D.W. Brammer, A. Garcia and H.G. Rush. 2015. Biology and diseases of Rabbits. Chapter 10. p. 411-461. In: James G. F., L.C. Anderson, G.M. Otto, K.R. Pritchett-Corning and M.T Whary (eds). Laboratory Animal Medicine (3rd Edition). American College of Laboratory Animal Medicine. Academic Press, Elsevier, Cambridge, Massachusetts, USA. https://doi.org/10.1016/B978-0-12-4095274.00010-9

Mogensen, T.H. 2009. Pathogen recognition and inflammatory signaling in innate immune defenses. Clin. Microbiol. Rev., 22(2): 240-273. https://doi.org/10.1128/CMR.00046-08

Moore D.M., K.L. Zimmerman and S.T. Smith. 2015. Hematology of laboratory Rabbits. Vet. Clin. Exot. Anim., 18: 9-19.

Mwaniki, Z., M. Neijat and E. Kiarie. 2018. Egg production and quality responses of adding up 
to $7.5 \%$ defatted black soldier fly larvae meal in a corn-soybean meal diet fed to Shaver White Leghorns from wk 19 to 27 of age. Poult., 97(8): 2829-2835. https://doi.org/10.3382/ps/ pey118

Rahman, M.Z., A. Reza, M.A. Siddiki, M.I. Hossain, M. Asaduzzaman and M.M. Rahman, 2015. Effect of pellet and mash feeding on the performance of growing rabbit. Bangladesh J. Anim. Sci., 44(2): 100-105. https://doi. org/10.3329/bjas.v44i2.26008

Sieske, L., G. Janssen, N. Babel, T.H. Westhoff, R. Wirth and M.Pourhassan. 2019. Inflammation, appetite and food intake in older hospitalized patients. Nutrients. 11(9)1986: 1-10. https:// doi.org/10.3390/nu11091986

Zotte, A.D. and Z. Szendrö. 2011. The role of rabbit meat as functional food. Meat Sci., 88: 319-331. https://doi.org/10.1016/j.meatsci.2011.02.017 